\title{
Labour repression and social justice in Franco's Spain: the political objectives of compulsory sickness insurance, 1942-1957
}

\author{
Jerònia Pons Pons \\ University of Seville
}

Margarita Vilar Rodríguez

University of Corunna

\begin{abstract}
:
This article analyzes the basic characteristics of the labor and social policies of the Franco dictatorship established in Spain after the Civil War (1936-1939), and the links which existed between them. The offer of support to working families was presented through a paternalistic discourse of 'social justice' which was combined with tough repressive measures in the labor market. Within this context, compulsory social insurances pursued a political end, as they served to mitigate social tensions in a context of worker repression and harsh living conditions. Sickness insurance was a key element in this strategy, and it turned out to be very economical for the dictatorship, as the burden of financing the system was placed on employers and, above all, the workers themselves. This led to financial and management problems within a system providing imperfect coverage, with low benefits and serious inequalities in protection. Consequently, Spain moved away from other advanced countries which, at this time, were establishing their welfare states on the basis of two pillars: the universalization of benefits and the redistributive character of the system from a social point of view.
\end{abstract}




\section{Introduction}

In the first half of the twentieth century fascism was not an exclusively German-Italian phenomenon; the Francoist regime - led by Franco (El Caudillo) - shared many of the characteristics that sustained the totalitarian regimes of Hitler (Der Führer) and Mussolini ('Il Duce). Common elements that can be highlighted include the concentration of power, the control of the means of production and communication, repression and violence, obedience and control of the masses. However, it must also be borne in mind that the Spanish case had some peculiarities in comparison with the Italian and German dictatorships with regard to its origin, duration and economic successes. In particular, Franco came to power through a coup d'état which led to a civil war, his dictatorship survived the fall of the fascist Axis powers by some thirty years and his economic successes were more limited.

The Spanish Civil War (1936-1939), which broke out after the failed coup d'état of July 1936 against the existing democratic regime, led to closer relations with the German-Italian axis, as both countries supported the military rebels from the very beginning of the conflict. After his victory in Spain's Civil War, and until the fascist armies lost the Second World War, Franco kept up a close relationship with the Axis powers, although in a position of subordination to some extent. There is no doubt that, until 1945, the Franco dictatorship drank from the ideological fountain of both fascist leaders and unashamedly copied some of their policies and propaganda. ${ }^{1}$

The situation changed after the Allied victory in the Second World War. The political isolation of Franco in the international arena, and the long and profound economic crisis the country suffered during the extended postwar period, forced the Spanish dictatorship to play down the most visually fascist aspects of its regime in order to guarantee its own survival. From then on, the Franco dictatorship underwent a process of metamorphosis, transforming

\footnotetext{
${ }^{1}$ Bowen, Spaniards and Nazi Germany, 139 and Bessel, Fascist Italy and Nazi Germany, 4-7.
} 
from an arbitrary, semi-fascist, personal dictatorship into a new identity to be found in socalled 'Catholic corporativism'. ${ }^{2}$ But this process was merely one of cleaning up its image, as the essential pillars of the dictatorship did not change.

After Franco took power, Spain endured a long and extremely tough post-Civil War period with spectacular falls in the main economic indicators and an alarming step backwards in terms of education and welfare in a context of deprivation of human, social and political rights. The 1935 income level of the Spanish economy was not regained until fifteen years later and the income trend line prior to the Civil War was not reached until 1956. As a result, Spanish convergence with respect to other European countries was reduced to an all-time low in 1960 (53 percent). ${ }^{3}$ In a country subjected to rigid interventionism and autarky, where hunger and sickness were rife and capital resources and technology were scarce, labor became the cheapest and most abundant factor of production. ${ }^{4}$ Within this context, employers opted for the intensive use of labor in the production processes, taking advantage of its low cost and the guarantee of discipline and obedience in a framework of repression. But the laborintensive model did not completely satisfy employers. The dramatic fall in real wages reduced demand in a domestic market where they were obliged to sell their production, given the

\footnotetext{
${ }^{2}$ The term 'Catholic corporativism' refers, in this paper, to the utilization of the Catholic religion as an element of social cohesion and interaction in a context in which traditional values were defended and there was an educational intent (more propagandistic than real) aimed at achieving national harmony and solidarity. See Tusell, La dictadura de Franco.

${ }^{3}$ Data calculated on the basis of Prados, El progreso económico de España, 177. European average of 12 countries. The economic recovery of the country only started in 1959 with the approval of the Stabilization Plan. ${ }^{4}$ Barciela, Autarquía y mercado negro; Catalan, 'La reconstrucción franquista'; Barciela, López, Melgarejo and Miranda, La España de Franco; and Prados, El progreso económico.
} 
export limitations established by the dictatorship. ${ }^{5}$ On the other hand, import quotas and the restrictions imposed on the entry of foreign capital also meant that normal production was impossible and these conditions limited investment, the key driving force of economic growth.

According to the regime's philosophy, work was considered to be a strategic tool with three main objectives. First of all, labor policy served as an instrument of repression and control of the working classes, identified as the losers of the war and enemies of the regime. Meanwhile, fear and repression favored the 'acceptance' of the Francoist regime's ideological principles and conditioned both the public and private lives of the population. ${ }^{6}$ Second, the Francoist regime used its wage policy to shape the country's social structure in accordance with its political interests. The economic, political and social framework established by the dictatorship helped to pass economic costs onto the workers. ${ }^{7}$ Finally, the abundant, cheap and domesticated labor force compensated employers for part of the costs which resulted from the lack of capital resources, technology and raw materials during the autarkic period. ${ }^{8}$

The system of social insurances introduced by the Franco dictatorship was also an indispensable instrument within the overall strategy of propaganda and subjugation of the workers. In particular, sickness insurance played a key role in the dictatorship for two fundamental reasons. First of all, before the Civil War, the Spanish state had only regulated

\footnotetext{
${ }^{5}$ The fall in real industrial wages per hour worked in the post-Civil War period reached, on average, 60 percent with respect to the prewar period. See Vilar, 'La ruptura postbélica' and Vilar, Los salarios del miedo.

${ }^{6}$ Richards, Un tiempo de silencio.

${ }^{7}$ See Vilar, 'La distribución funcional de la renta'.

${ }^{8}$ Catalan, La economía española; Sánchez and Tascón, Los empresarios de Franco.
} 
three social insurances: industrial accidents (1900), old age (1919) and maternity (1929). ${ }^{9}$ During this period the state did not legislate, or regulate or finance health care provision, which remained in the hands of mutual societies and private companies. This resulted in substantial deficiencies in the coverage of the population. The dictatorship took advantage of the weakness of these institutions, and of the gap in state regulation of the risk of sickness, to convert this insurance into a key element of its political propaganda. Furthermore, through this initiative, the Franco regime managed to eliminate one of the remaining strongholds of the working-class movement, as some of the friendly societies had a trade union origin.

Second, the depressed economy of the long post-Civil War period led to a deterioration in living conditions for the majority of the population. This social panorama led to the appearance of illnesses due to insufficient vitamins, which coincided with the proliferation of infections stemming from the lack of hygiene and salubrity. Infant mortality rates rose by 33.3 deaths per thousand births between 1935 and 1941 and epidemics of typhus and tuberculosis depleted the little strength remaining to the weakest. ${ }^{10}$ The figures are, to say the least, chilling. From 1941 to 1945, 310,470 people died of tuberculosis, 15,259 of typhoid, 3,615 of typhus and 7,801 of syphilis, figures that were much higher than those for the prewar period. Cases of malaria, pneumonia and other illnesses also increased dramatically.

In August 1941, the Directorate General for Health Care (Dirección General de Sanidad) warned that 'during the next winter there could be between 1.7 and 2 million deaths due to

\footnotetext{
${ }^{9}$ Two institutions played a key role in the advances of social policy in Spain at the beginning of the $20{ }^{\text {th }}$ century: the Institute for Social Reform (Instituto de Reformas Sociales or IRS) and the National Welfare Institute (Instituto Nacional de Previsión or INP). See Palacio, La construcción del Estado Social.

${ }^{10}$ According to R. Nicolau, the infant mortality rate in 1935 was 115.3 per thousand and in 1941 it was 148.6 per thousand. Nicolau, 'Población, salud', 131. The deaths from sickness were obtained from the annual statistical yearbook, Anuario Estadístico de España (1955), 751.
} 
starvation or illnesses related to malnutrition'. ${ }^{11}$ This calamitous situation could put the country's public health in danger and, above all, could threaten both the desired 'social order' and the process of attracting the masses that was being pursued by the regime's propaganda machinery. Only within this context is it possible to understand the dictatorship's interest in introducing a compulsory sickness insurance which also served as a propaganda tool by demonstrating the 'goodness and kindness of the regime'.

Once the subordination of the workers had been achieved through the repressive measures that were imposed by means of strict labor regulation, it was necessary to ensure a certain degree of social stability. In order to achieve this aim, the regime needed to show a 'friendlier' face to workers. Social insurances and family policies, which included goals typical of fascist regimes such as encouraging a higher birth rate or defending maternity and the traditional home, fulfilled this role to perfection. ${ }^{12}$ The offer of support to working families was presented by way of a paternalistic discourse in favor of 'social justice'. ${ }^{13}$

The social regime referred to was an imperfect system of limited coverage and unequal protection. For example, the scope of the benefits provided by the system excluded such large and important sectors of the working population as agricultural workers, who comprised 50.5 percent of Spain's total active population in $1940 .{ }^{14}$ Furthermore, the state decided to make no contribution whatsoever to its financing and limited itself to assuming a role as regulator,

\footnotetext{
${ }^{11}$ Barciela, López, Melgarejo and Miranda, La España de Franco, 27.

${ }^{12}$ Molinero, 'Mujer, franquismo, fascismo' and Bernabeu-Mestre, 'Madres y enfermeras'.

${ }^{13}$ The term 'social justice', widely used by the authorities of the Franco regime, did not respond to goals of redistribution and equity but rather to a propaganda discourse aimed at winning over the masses. See Molinero, La captación de las masas, 37.

${ }^{14}$ Data proceeding from Nicolau, 'Población, salud y actividad'. In the depressed economy of the Spanish postwar period many families returned to the countryside, where they still had family ties and could cover their food requirements more easily.
} 
demanding the requisite fees from whoever was obliged by law to contribute to the system and regulating payments when possible beneficiaries met the conditions laid down by law. The Franco regime, therefore, in the last resort, defended the principle of self-financing of the social regime. ${ }^{15}$ Social insurances were basically to be financed by employers and workers, who had to dedicate a percentage of their meager wages to these contributions and received derisory benefits that were more and more depreciated by the high inflation rife at this time. Consequently, the workers became the main victims of the flaws in the model of protection.

The Francoist system of social insurances had many elements in common with the German and Italian dictatorships. This proximity can clearly be seen in the case of sickness insurance. On the one hand, the Franco dictatorship adapted the comprehensive sickness insurance model applied in Nazi Germany. It was an insurance of the Bismarckian tradition, but subject to strict state control. On the other hand, it was also inspired by the Italian organizational system. That is to say, a system based on a multiplicity of managing bodies and institutions controlled by the party with poor results in terms of coverage of the population and medical care. ${ }^{16}$

This article takes the situation outlined above as a starting point, and is divided into three sections. The first analyzes the basic characteristics of the labor and social policies of the Franco dictatorship in the first decades after the Civil War, and the links which existed between them. The second section analyzes the political objectives of the sickness insurance established by the Franco dictatorship, the only social insurance that had not been legislated in Spain prior to the Civil War. Through a study of the financing, coverage and management of this insurance, we intend to demonstrate the reality which lay beyond the results

\footnotetext{
${ }^{15}$ A similar model had already been applied in Mussolini's Italy, where Francoism copied some aspects from. See Molinero, La captación de las masas, 126.

${ }^{16}$ Zamagni, Economic History; Owen, The German Economy.
} 
disseminated by the Francoist regime for propaganda purposes. We also examine how the dictatorship's unwillingness to finance the expensive sickness insurance with public funds made it necessary to resort to a contributory system financed by employers and workers which turned out to be unviable in the medium term. The final section sets forth the main conclusions.

\section{Links between labor policy and social insurances under Franco's dictatorship}

The basic principles of the rebel government's labor and social policy were clearly established during the first months of the Spanish Civil War. First, all political and trade union activity was prohibited and then trade union organizations and political parties were dissolved while, at the same time, all their property was confiscated. ${ }^{17}$ Before the conflict had finished, the so-called Fuero del Trabajo or 'Employment Code' (1938) laid down the guidelines for the functioning of the labor market which were to be in force during almost forty years of dictatorship.

In the first place, the Fuero designated the state as the supreme supervisory body charged with the responsibility of establishing the basic rules of labor relations. Secondly, the legal framework was aimed at expelling married women from the labor market. Consequently, paid work became institutionalized as a male prerogative. ${ }^{18}$ Finally, the Fuero established the grouping of employers and workers within a single vertical trade union at the service of the state under the principles of 'unity, totality and hierarchy' ${ }^{19}$ Two years later, the Law of

\footnotetext{
${ }^{17}$ Decree of 25 September 1936, no. 131 (Official State Gazette [Boletín Oficial del Estado], BOE 28/09/1936). Order of 10 January 1937 (BOE 11/01/1937) and Decree of 19 April 1937, no. 255 (BOE 20/04/1937).

${ }^{18}$ Sarasúa and Gálvez, ¿Privilegios o eficiencia?, 39. Although, in practice, economic necessity forced women to continue working in secrecy without guarantees or labor rights.

${ }^{19}$ The single vertical trade union was an organization integrated into the state itself and comprising both workers and employers. See Aparicio, 'Sobre los comienzos'.
} 
Trade Union Unity (Ley de Unidad Sindical) of 1940 converted the fascist political party La Falange into the only organization authorized to channel labor conflicts. ${ }^{20}$ Although the vertical syndicate performed an important function in the dictatorship's repressive machinery, effective control over many of the workers was exercised directly by employers from within their own companies. ${ }^{21}$ This legal scenario completely destroyed the capacity of wage earners either to protest or to negotiate. The initial investment in terror brought the dictatorship great dividends in the long term, in terms of consent and control. ${ }^{22}$

Under these circumstances, the 'right' to work became a 'duty' to the motherland and the act of working was considered to be a 'service', a term which combined a military sense with connotations of servility. ${ }^{23}$ Likewise, the word 'worker' was substituted by the word 'producer', a term which introduced a certain dehumanization of the workforce and moved away from the classic concept of class struggle. Gangs of workers came to be called 'militias', military terminology which implied discipline and submission. This new concept of labor organization spread through the occupied territories as the rebel army advanced, and its basic characteristics were to remain unchanged once the war was over.

\footnotetext{
${ }^{20}$ Ley de Unidad Sindical (Law of Unification of Unions) of 26 January 1940 (BOE 31/01/1940).

${ }^{21}$ To describe this role, J. Babiano uses the term caudillo-empresario ('caudillo-businessman'), see Babiano, Paternalismo industrial. The Fuero del Trabajo reinforces the figure of the jefe de empresa ('company boss'), who wielded the real power when it came to controlling the workers within the company.

${ }^{22}$ Preston, Franco. Caudillo de España, 971. The Ley de Seguridad del Estado (Law of State Security) of 29 March 1941 (BOE 11/04/1941) also contributed its dose of terror by punishing subversive and anti-patriotic behavior with the death penalty.

${ }^{23}$ For more on this issue, see Vilar, Los salarios del miedo.
} 
The Franco dictatorship also established a regime of social coverage which fitted in perfectly with its ideology. ${ }^{24}$ Noteworthy within this new legislative framework were the Compulsory Old Age and Invalidity Insurance (Seguro Obligatorio de Vejez e Invalidez) which replaced the old retirement pension (Retiro Obrero); the Compulsory Sickness Insurance (Seguro Obligatorio de Enfermedad), which from 1948 also included maternity insurance (Decree of 9 July 1948); Compulsory Accident Insurance (Seguro Obligatorio de Accidentes), which maintained the basic characteristics of the prewar period; and, finally, the Compulsory Professional Illness Insurance (Seguro Obligatorio de Enfermedades Profesionales) which came into effect in $1950 .{ }^{25}$ The dictatorship passed a whole string of legislation dealing with various social matters (social insurances, family allowances, etc.) but, in practice, levels of protection remained low, both in terms of the population covered and in terms of the actual amounts of benefits and subsidies, which remained very low at a time of high living costs.

In general, the dictatorship opted for a system of centralized management where the state assumed direct control of social insurances with the help of the National Welfare Institute (Instituto Nacional de Previsión, INP). The same as in Mussolini's Italy, the Francoist state reserved for itself the role of controller but not that of manager of the welfare system. ${ }^{26}$ The management of the Francoist social policy was left in the hands of a great number of different

\footnotetext{
${ }^{24}$ The National Welfare Institute was reorganized on 15 June 1938. See Montero, Orígenes y antecedentes, and Castillo, Solidaridad, Seguridad, Bienestar.

${ }^{25}$ Moreover, in 1944 the Franco regime repealed the legislation in force dealing with unemployment insurance.

This area was neglected by the state until the creation of the National Unemployment Insurance in 1961. See Benjumea, 'Sanidad y desempleo', 466.

${ }^{26}$ According to the principles of the Italian Labor Charter passed in 1927, the state should not concern itself with anything more than coordinating and unifying the welfare system and its institutions. See Bertini, 'Il fascismo', 190.
} 
bodies, under the control of the Ministry of Labor. These so-called 'collaborating bodies' served as a political platform for their leaders and as a breeding ground of support for the dictatorship, thanks to the jobs that they provided and the business opportunities they created. ${ }^{27}$ Second, the financial capitalization system applied in the prewar period was replaced by another of pay-as-you-go, which modified the essence of the state insurance system. It is only necessary to recall that, in a capitalization system, the amount collected is channeled into low-risk investments, and the profitability of these investments enable the future payment of pensions to be covered. On the contrary, in the pay-as-you-go system the benefits paid at any one point in time are funded by the contributions being paid at the same point in time. This involves a greater risk from a financial point of view, as current benefits are only guaranteed by the number and capacity of contributors or wage earners who are presently in employment. The risks of this method increased greatly during the post-Civil War period, due to the state's lack of commitment to financing a welfare system under threat from an increasingly inflationary situation.

Finally, changes were also introduced in the nature of the contributions to social insurances. Workers, unlike during the period prior to the Civil War, were also obliged to contribute a percentage of their basic wage. ${ }^{28}$ Furthermore, employers' contributions and pensions went from being fixed to being proportional to real wages at a time when workers' purchasing power was plummeting and the wages earned were insufficient to get by. For this reason, benefits such as old-age insurance, which already started off from very low levels of coverage, slumped dramatically. In an attempt to deal with this serious situation, the

\footnotetext{
${ }^{27}$ The 'collaborating bodies' included companies, employers' industrial accident insurance mutuals and social insurance mutuals which reached special agreements of collaboration with the National Welfare Institute to manage the sickness insurance. The first agreements were signed in 1944.

${ }^{28}$ Before the Civil War it was agreed that, provisionally, contributions would be paid by the state and employers, with the workers being exempted from payment due to their precarious situation, Hermida, 'El retiro obrero'.
} 
dictatorship did not reform existing insurance schemes, but instead created a complementary regime of social insurances that were also compulsory, linked to public or semi-public institutions with their own legal personality, namely mutualidades laborales (workers' friendly societies) and montepíos laborales (also similar to friendly societies). Their primary objective was the granting of supplementary benefits. In other words, in view of the limited sources of financing, the dictatorship decided on supplementary self-financing for professional groups that had the possibility of coming up with the necessary funding. ${ }^{29}$

Within this system, the internal structure of labor costs was extremely complex. In order to simplify somewhat, we can consider the labor costs of an industrial worker to be divided into three large components. First, compulsory contributions, which in 1954 comprised approximately 22.3 percent of total labor costs per worker and included five basic items: compulsory contributions to social insurances accounted for 13 percent (these included family allowance, old age, accidents, sickness and family responsibilities), while 1.5 percent went on compulsory union fees, 1 percent on the national health care plan (this contribution refers only to health care infrastructure), 0.8 percent on professional training and 6 percent went to a Montepío laboral. Apart from these compulsory contributions, workers could also contribute voluntarily to other insurances (i.e. silicosis, unemployment) and to cover the wear and tear of tools, among others. Generally speaking, however, their meager incomes did not allow them to pay for these voluntary items.

As a second component of labor costs, workers received supplementary benefits of a pseudo-welfare character, which constituted a direct remuneration for workers but which had absolutely nothing to do with their qualifications or performance, such as family benefits, a

\footnotetext{
${ }^{29}$ Workers' friendly societies and montepíos started to appear from 1946 onwards and were integrated into the so-called Servicio de Mutualidades y Montepíos Laborales as an autonomous body within the Ministry of Labor. The benefits that the workers' mutuals offered supplemented the insufficient income coming from social insurances. See González Murillo 'El mutualismo laboral’ and Redecillas, El mutualismo laboral.
} 
bread subsidy (to buy basic foodstuffs), a rain subsidy (to buy rain clothes for work), bonuses and all the other social charges. This was a method used by employers to top up legal wages that were insufficient for the workers' survival. The system of supplements had two advantages for employers. On the one hand, the items were optional and discretionary. On the other hand, most of these items were linked to workers' 'good behavior' rather than to efficiency or effectiveness at work. Moreover, it must also be taken into account that these items were not officially considered to be social contributions, and hence they did not increase employers' contributions.

The third component of labor costs was their income as compensation for the work they had actually done. This last component only comprised 38.53 percent of labor costs per worker in $1954 .^{30}$ Moreover, this was so in a country where workers were obliged to work overtime or hold dual or multiple jobs, to the extent of completing working days of 10 or 12 hours, which did not even guarantee the survival of the immediate family.

Furthermore, under the new rules of the Francoist welfare system, in order to calculate the contributions to the compulsory social insurances, the total income of a worker was taken into account, including supplements, subsidies and benefits in kind, without any limit. ${ }^{31}$ The relation between the wage that determined social security contributions and the actual wage for work done was not a priori a problem, because low, regulated wages resulted in small, stable social contributions. But the increase in the actual wage for work done, above all in the nineteen fifties, had immediate repercussions on social contributions, which were inconvenient for employers. Employers preferred to reduce the social costs per employee and increase the wage for work done, with the aim of stimulating productivity and improving

\footnotetext{
${ }^{30}$ Data corresponding to 1954. ABC newspaper, 15 June 1954 and CSCCIN, Comercio, Industria y Navegación de España, 1955, No. 85.

${ }^{31}$ BOE 18/01/1949, No. 18.
} 
workers' purchasing power, but they wanted to avoid a greater increase in labor costs which would result from the consequent increment that a pay rise would produce in social contributions.

In response to employers' complaints, the dictatorship modified contributions to the system of social insurances at the end of the fifties. First of all, legal limits were established for the percentages of contributions in relation to wages. ${ }^{32}$ Secondly, by means of a decree of 21 March 1958, wage increases offered voluntarily by companies, productivity bonuses and all other incentives and payments related to performance were excluded from social contributions. ${ }^{33}$ These measures meant the start of a definitive break between wage policies and social policies and met part of the employers' demands, but they also put the viability of the model at risk in the medium term. The reduction of contributions within a distribution system meant that, in the medium term, it would be very difficult to finance the benefits in force at that time. In order to counteract this negative effect, the state committed itself to contributing more actively to the financing of social insurances. As a first step, an extraordinary credit of 1,125 million pesetas was granted to the National Welfare Institute in order to cover pending social provisions, but nevertheless an annual state contribution was not legally established.

For the first time, the tacit principle of the self-financing of the social regime seemed to be broken, and the way was laid open to the nationalization of the system. But the limited funds that the state could count on were unable to prevent the progressive decline of benefits due to the system's lack of finances. ${ }^{34}$ During these years the state did not commit itself fully

\footnotetext{
${ }^{32}$ By a decree of 23 March 1956, 4.5 percent of wages was set as a limit for workers' social contributions, see BOE $27 / 03 / 1956$, No. 87 . Another 4.5 percent of wages was paid by the company, but the employers' percentage increased, in general, to 14.50 percent a few months later. See BOE 30/10/1956, No. 304.

${ }^{33}$ BOE 01/04/1958, No. 78.

${ }^{34}$ Pereda and Desdentado, 'La política de salarios'.
} 
and limited itself to patching up the system by way of extraordinary credits which served to guarantee the payment of social insurance provisions, but this did not prevent the scheme from entering a terminal decline in the nineteen sixties. ${ }^{35}$ As contributions were frozen at a time when wages were rising, pensions and social benefits lost purchasing power, and at the same time benefits in kind (such as medical and pharmaceutical care) were deteriorating. In order to find a solution to this situation, the Basic Law of 1963 was passed, the origin of the present Social Security system. This introduced, among other innovations, a new formula where contributions were fixed on the basis of theoretical contribution wages that were unrelated to real wages. ${ }^{36}$

\section{Compulsory Sickness Insurance under the Franco dictatorship}

After a Republican stage (1931-1936) of considerable advances in social insurances and especially in public health care, the Franco dictatorship eliminated the most socially advanced elements from its discourse. ${ }^{37}$ Between 1931 and 1933, during the initial left-wing term of Republican government, there was an important change in public health care policy with the incorporation of important professionals and intellectuals who initiated a health care reform in Spain. Parallel to this, a medical-social model was promoted based on centers of rural hygiene

\footnotetext{
${ }^{35}$ See the law of 26 December 1957 by which the state granted an extraordinary credit of 375 million pesetas to maintain social provisions. BOE 28/12/1957, No. 324.

${ }^{36}$ The Basic Law (Ley de Bases) of 30 December 1963 authorized the change from a fragmented system of social insurances to an integrated Social Security system. See Blanco, Planificación de la seguridad social; Serrano and Malo de Molina, Salarios y Mercado de Trabajo.

${ }^{37}$ See, for example, the contributions of Marcelino Pascual at the head of the Directorate General for Health Care (Dirección General de Sanidad), which increased its budget significantly. See Bernabeu-Mestre, 'La utopía reformadora' and for the social policy during the first two years of the Second Republic, see 'La política social'. For the advances in sickness insurance during the Second Republic, see Porras, 'El seguro de enfermedad' and Rodríguez Ocaña, 'La asistencia médica colectiva'.
} 
and they advocated quality specialized training with practical training periods abroad. ${ }^{38}$ Only compulsory sickness insurance had been omitted from prewar legislation. The Francoist regime took advantage of this still-pending matter in order to convert its Compulsory Sickness Insurance (SOE), passed by the law of 14 December 1942, into a key piece of the propaganda machine which surrounded its new social policy. ${ }^{39}$ The introduction of compulsory sickness insurance had little to do with Republican social advances and was carried out without taking into consideration professional collectives, as is shown by the fact that it was linked to the Ministry of the Interior and not to the Directorate General for Health Care. It received scant support by way of public funds and there was insufficient healthcare infrastructure. ${ }^{40}$

Unlike old age, maternity, unemployment or industrial accidents, sickness coverage had remained in the hands of the private sector prior to the Civil War. ${ }^{41}$ While the majority of European states had passed laws regulating sickness insurance before 1931, the Spanish government did not either legislate, or regulate, or finance this contingency before 1936. Within a format of voluntary insurance, the state limited itself to awarding small and sporadic subsidies, paid for out of a very limited state budget, to a handful of friendly societies providing medical-pharmaceutical care. Various factors hindered the implementation of sickness insurance. The most serious obstacles included, among others, the inefficient tax system, which put a brake on the possible increase in state income proceeding from direct

\footnotetext{
${ }^{38}$ Rodríguez Ocaña, 'The politics of public health'; Rodríguez Ocaña, 'Los servicios de salud pública'.

${ }^{39}$ BOE 27/12/1942, No. 361 and BOE 01/07/1944, No. 183. For the development of sickness insurance in the context of the Franco regime's social policy, see García Padilla, 'Historia de la acción social'; Benjumea, ‘Sanidad y desempleo’; González Murillo, ‘La política social del franquismo’ and González Murillo, ‘El franquismo social'.

${ }^{40}$ Marset, 'Estructura político-administrativas'.

${ }^{41}$ Pons and Vilar. 'Friendly societies' and the bibliography listed therein.
} 
taxes, and which in turn impeded the creation of all the health care infrastructure needed to introduce sickness insurance for the entire population. ${ }^{42}$

On the other hand, the opposition of the majority of employers, professional medical associations, mutuals and insurance companies persisted, as they felt their private business to be under threat. ${ }^{43}$ Even the workers themselves were reluctant to accept an insurance based on contributions, as they were hoping for greater state coverage without having to make contributions, as was the case with old age pensions.

Taking advantage of these circumstances, the Franco dictatorship sold the initiative as the cornerstone of the social advances promoted by the regime. The elaboration of the legal bases of the insurance and its implementing regulation took place in the middle of confrontations for the control of the National Welfare Institute. In a first stage after its reconstitution of 22 August 1938 it was under Catholic-social influence with an important role for former members of the institute, such as Luis Jordana de Pozas. However, starting from 1941 and until mid-1945 (the time when fascism was defeated in a large part of Europe) there was a powerful Falangist influence with the arrival of Minister Girón at the Ministry of Labor. ${ }^{44}$ The Falange promoted the compulsory sickness insurance as if it were its own initiative, excluding the Directorate General for Health Care (in the hands of Catholic and monarchist military circles), which was left to run preventative campaigns, including the fight against tuberculosis. ${ }^{45}$ While the National Welfare Institute was losing power and influence,

\footnotetext{
${ }^{42}$ Comín, Hacienda y economía.

${ }^{43}$ In general, the professional medical associations opposed the introduction of a compulsory sickness insurance because they were afraid that it would lead to a reduction in their incomes. However, there were also doctors who supported social medicine, above all during the Republican period (1931-1936). See, Rodríguez-Ocaña, 'The politics'.

${ }^{44}$ For this period, see Álvarez Rosete, 'Elaborados con calma', and Molinero, La captación de las masas.

${ }^{45}$ Molero, 'Enfermedad y previsión social’ and Álvarez Roseta, ‘¡Bienvenido, Mister Beveridge!'.
} 
the Ministry of Labor allowed the Obras Sindicales of the Falangist trade union to emerge and to become stronger.

The dictatorship was also able to overcome the opposition of the medical profession to compulsory sickness insurance through a variety of means. ${ }^{46}$ First of all, by diluting the medical associations in the single vertical trade union. Second, a competitive system of authorization was established in order to gain entry to the body of doctors of the Compulsory Sickness Insurance. This professional opening, fomented by considerable salary increases, provided stability in terms of work and income for doctors linked to the compulsory sickness insurance.

The law of 1942 established compulsory coverage against three social risks: sickness, maternity and death. ${ }^{47}$ The legal obligation to affiliate to the insurance did not commence until July 1944 and, starting from 1 September of the same year, the right to receive benefits came into effect. Under the new legal figure, all producers over the age of 14 employed in industry and services whose income did not initially exceed 9,000 pesetas a year were compulsorily insured against sickness. ${ }^{48}$ In 1944, the difficulties in the management and financing of the insurance obliged the authorization of the signing of agreements with

\footnotetext{
${ }^{46}$ Criado, Problemas sanitarios.

${ }^{47}$ The maternity insurance had been created by decree on 22 March 1929 and was linked to the system of pensions (known as retiro obrero) from its introduction until its absorption by the compulsory health insurance by a decree of 9 July 1948. González Murillo, Pedro. 'El franquismo social: propaganda', 108. For the maternity insurance before the Civil War, see Cuesta, 'Hacia el seguro de maternidad'.

${ }^{48}$ Regulation for the application of the compulsory health insurance, BOE 28/11/1943. The upper limit for salaries was very low and excluded a substantial number of workers from the system. The situation was so scandalous that the dictatorship raised the legal upper limit for salaries several times. See Bikkal, La Seguridad
} Social, 438. 
collaborating bodies. ${ }^{49}$ On the other hand, article 10 of the law guaranteed the insured and family members under his protection 'complete medical care both in general medical services and in specialities'. However, in the beginning actual coverage was very limited. ${ }^{50}$ The benefits of the insurance were implemented in different stages. During the first years, the insurance only offered general medical care and pharmaceutical treatment for a maximum period of 26 weeks a year for the insured and 13 for their family members. Later, in 19471948, specialized medical care was incorporated and also hospitalization up to a limit of 12 weeks, or 6 weeks for immediate family.

The implementation of compulsory sickness insurance was riddled with serious difficulties. ${ }^{51}$ First, it was necessary to organize the medical and pharmaceutical services, overcoming the reticence that these professional groups felt towards the public health care service. Second, applying compulsory sickness insurance required a great economic effort, as its functioning demanded a substantial expenditure on infrastructure and human and material resources. Compulsory sickness insurance, therefore, the cornerstone of the propaganda of the Franco regime's social policy, was faced with enormous problems due to the state's lack of resources, a result of the postwar economic crisis, autarky and the regressive tax system. It must be taken into account that the Spanish tax system reformed in the $19^{\text {th }}$ century did not undergo any profound changes until the end of the Franco dictatorship. ${ }^{52}$ The first Finance ministers of the Franco regime were against a progressive tax reform that would increase the tax burden; their retouches to the tax system did little to increase tax collection and, as they failed to achieve a balanced budget, they opted to sacrifice economic and social expenditure. The prevailing tax system was intended to benefit the social groups that had helped the rebel

\footnotetext{
${ }^{49}$ Bikkal, La Seguridad Social, 437.

${ }^{50}$ For more about the beneficiaries, see Benjumea, 'Sanidad y desempleo'.

${ }^{51}$ Alberti, 'La asistencia sanitaria' 308-312.

${ }^{52}$ Comín, Hacienda y economía.
} 
faction to win the war; these were the social classes that would have been worst affected if a progressive income tax had been established, and if there had also been an efficient management of tax collection to effectively curb fraud.

In a political context in which tax reform was not viable, the groups that supported the regime, which included employers, preferred a social insurance system based on contributions that were proportional to wages. Low labor costs and a labor framework favorable to their interests compensated the compulsory nature of contributing for their employees. The contributory system, which placed a greater burden on the workers who received very low wages, enabled the introduction of compulsory sickness insurance. However, around 1953, the prevailing contributory system proved to be insufficient to finance the growing costs of health care provisions, medical fees and the building of health care facilities.

These problems made it extremely difficult to implement this insurance. The most important deficiency was without a doubt the financial one, as the lack of resources conditioned both the management of the scheme and the required health care infrastructure. The financial problem was overcome in the first ten years with funds accumulated from other insurances and a system of contributions in which employers and workers paid a premium for the insurance coverage, with practically no contribution whatsoever from the state. As regards difficulties to manage the scheme, agreements were signed with private entities which used their human resources and their health care infrastructure for the implementation of this insurance. We examine these two aspects in greater depth below.

Initially, compulsory sickness insurance was financed with a start-up capital of fifty million pesetas advanced by the National Welfare Institute, proceeding from the funds collected for other social insurances. By an order of 3 June 1944, a premium was fixed equivalent to 5.013 percent of earned income, to be paid equally between employers and workers, and which in practice constituted the main source of financing for the compulsory 
sickness insurance (Table 1). ${ }^{53}$ Of the total proceeding from the contributions of workers and employers, 2.45362 percent was then deducted to contribute towards the inspection of health services. Therefore, the same as occurred with other insurances, the contributions of employers and workers ended up being the main source of financing. Moreover, the state administration itself was actually being financed with the contributions of employers and workers to some extent, as they were paying for the inspections which were to control the application of the insurance. As a result, the insurance was confronted with serious economic limitations which led to reduced economic benefits and limited health care provisions.

Table 1. The basic figures of Compulsory Sickness Insurance (pesetas in nominal terms)

\begin{tabular}{|l|l|l|l|l|}
\hline & $\begin{array}{l}\text { Collected through } \\
\text { contributions }\end{array}$ & No. companies & State & Benefit payments \\
\hline 1945 & $284,706,228$ & 274,155 & - & $198,687,184(1946)$ \\
\hline 1948 & $882,989,416$ & 373,953 & - & $535,374,038$ \\
\hline 1951 & $1,701,447,965$ & 369,015 & - & $1,381,823,393$ \\
\hline 1954 & $2,649,900,000$ & 406,613 & $71,400,000$ & $2,509,827,979$ \\
\hline 1957 & $4,215,700,000$ & 442,900 & $76,500,000$ & $4,653,159,262$ \\
\hline
\end{tabular}

Note: The figures include both the operations carried out by the National Sickness Insurance Fund and those carried out by collaborating bodies. Payments include both economic benefits

\footnotetext{
${ }^{53}$ However, in 1947, the contribution increased to 6.25 percent and, later, from 1 January 1954, the contributions for compulsory health insurance were now $10 \%$ of the basic wage, with $7 \%$ corresponding to the employer and $3 \%$ paid by the insured. See Bikkal, La Seguridad Social, 438.
} 
(for sickness, maternity and funeral expenses) and payments for medical and pharmaceutical services and hospital care.

Source: From CSCCIN, Comercio, Industria y Navegación de España, August-September, 1955, 86; Bikkal, 'La Seguridad Social en España', 441 and AEE, Anuarios Estadísticos de España, 1955 and 1960. The state contributions come from Rull, 'Consecuencias fiscales', 42.

With the start of the second stage of compulsory sickness insurance, from 1 January 1947, the coverage of medical and surgical specialities was introduced. This new stage entailed new financing requirements, especially for creating hospitals and health centers for medical specialities. In order to meet these extra expenses, the authorities resorted to increasing the premium paid by employers and workers. The new premium was initially set at 6.35 percent of earned income, but as this turned out to be insufficient the premium was increased until it reached 8 percent in $1948 .^{54}$ At the end of this year, the contribution for compulsory sickness insurance was included in a unified contribution for all social insurances, which amounted to 15.92 percent of wages and included the contributions for old age, sickness and family allowance. ${ }^{55}$ Meanwhile, the government had drawn up a plan of health care facilities in order to be able to put this second stage into practice. ${ }^{56}$ An order of 9 January 1947 created the obligation to pay 1.5748 percent of premiums collected into the National Sickness Insurance Fund. This amount was insufficient for the creation of the planned hospitals and health centers and so it was increased until the figure was doubled by an order of 23 January 1948 and reached 3.125 percent. Subsequently, on 29 December 1948,

\footnotetext{
${ }^{54}$ Compendio del seguro de Enfermedad, Madrid, 1949.

${ }^{55}$ González Murillo, 'El franquismo social', 61.

${ }^{56}$ For the initial problems, see the work of Bernal, El seguro obligatorio, Serrano, El seguro de enfermedad and INP, 'El seguro de Enfermedad'.
} 
it stabilized at 3 percent. This health care infrastructure was basically created through the efforts of the workers, given that the deduction of these quantities had a much greater impact on what were already low wages than on the profits of employers. Nevertheless, almost ten years after the establishment of compulsory sickness insurance and a system of financing based entirely on contributions, the state had to look for other financial resources. On 1 January 1952 the government authorized the National Welfare Institute to issue bonds to the value of 9,654 million pesetas. ${ }^{57}$ The contributions made by the state in 1954 and 1957 only comprised a small percentage of total funding (2.6 per cent and 1.8 per cent respectively) (Table 1). ${ }^{58}$

At the time the insurance was introduced, the lack of financing had exposed another of the problems of its implementation: its management. All the bureaucracy required for the collection of premiums, the payment of health care services or cash benefits, among other things, meant that both an administrative and a health care infrastructure were necessary. The solution came in 1944 when the National Welfare Institute signed agreements with private entities for the provision of the sickness insurance. On 2 March 1944 a decree was passed authorizing a special agreement between the National Welfare Institute and the so-called collaborating bodies. The Ministry of Labor's order of 8 March 1944 set down the rules and regulations of this special agreement. Mutual societies, companies and igualatorios (doctors' associations) that provided medical and/or pharmaceutical care, and those commercial companies that had organized some kind of health care provision or economic benefit before 18 July 1936, could apply to participate in the agreement.

Among the collaborating bodies most interested in reaching agreements with the National Welfare Institute were the Employers' Industrial Accident Mutuals, which already

\footnotetext{
${ }^{57}$ INP, Plan Nacional de Instalaciones Sanitarias.

${ }^{58}$ Rull, 'Consecuencias fiscales', 42.
} 
managed, along with commercial insurance companies, the branch of industrial accident insurance. ${ }^{59}$ The most important employers' mutuals had local branches to manage the premiums and dispensaries and clinics in the areas where they operated. Accident insurance had become an instrument of control over their injured workers and entailed low costs compared with other alternatives. For this reason, the mutuals, as representatives of the employers' interests, saw the special agreements to manage compulsory sickness insurance as a way of extending their control over sick or injured workers, by controlling the doctors who treated them and the duration of their treatment, and also as a way of managing the premiums that they paid, as well as those paid by the workers. By 1945, 228 collaborating bodies had been authorized. ${ }^{60}$ The contracts were drawn up for a period of ten years. The collaborating bodies covered 64.72 percent of the insured and 62.39 percent of beneficiaries as opposed to only 23.44 percent and 24.89 percent respectively covered by the National Sickness Insurance Fund. The private management of social insurances was decisive and indispensable for actually putting the government's social policy into practice throughout the entire period of the Franco dictatorship.

But the private management of sickness insurance accentuated the fragmented system of social insurances and led to unequal coverage of the insured, who did not have the same rights or obligations, due to the practice of risk selection among the collaborating bodies that could choose whether to accept the insured companies or not. ${ }^{61}$ These collaborating bodies

\footnotetext{
${ }^{59}$ Very few friendly societies that had covered sickness insurance among their workers up until 1944 signed special agreements in order to become collaborating bodies. They did not have the capacity to manage the insurance on a provincial scale, and nor did they have the financial capacity to pay the deposit required by the National Welfare Institute. In the majority of cases they wound up their business or they became cultural associations or leisure institutions.

${ }^{60}$ Pons, 'El seguro obligatorio'.

${ }^{61}$ Pons, 'El seguro obligatorio’ and González Murillo, ‘El franquismo social', 108.
} 
had to pay a deposit in order to be able to manage the insurance, and this varied depending on the geographical scope of the collaborating body. In return for their management, the collaborating bodies had the right to retain a percentage of the premiums collected to cover administration costs, and this is where, theoretically, they would make a profit. The majority of collaborating bodies were in debt in the medium term.

Although there was a certain obscurantism with respect to the results of the collaborating bodies managing these insurances, as at no time was a compilation of data dealing with the insurance as a whole published, a study made on the basis of 1953 data determined that the deficit of the collaborating bodies was on average 3.61 percent of the average premiums collected. ${ }^{62}$ The depreciation of assets of a health care nature was not included in this deficit, and neither were special and extraordinary provisions nor the 5 percent destined to finance regulatory reserves. If these variables were taken into consideration, the average deficit could have been as much as 8.6 percent. The deficit was a result of the scant growth of income with the passage of time (proceeding basically from wages and the number of insured) while, on the other hand, costs were increasing due to the extension of health care services, the use of antibiotics, the increase in the prices of pharmaceutical products, improvements in the remuneration of staff and the context of severe generalized inflation which led to a chronic budget deficit. ${ }^{63}$

In 1949, a financial adjustment was made in an attempt to solve the revenue problem but which, however, was not sufficient. Premiums were increased by 1 percent, the field of application was extended to wages of up to 18,000 pesetas a year, a proportional system of contributions according to wages was introduced and a wider concept of the basic wage for

\footnotetext{
${ }^{62}$ Gil, 'El Seguro Obligatorio', 64.

${ }^{63}$ Jordana, Los seguros sociales, 161 attributes the deficit of 1949 and 1950 to a 25 percent increase in pharmaceutical costs and medical fees.
} 
contributory purposes was established. The great problem was that real wages remained almost unchanged (at a lower level than in 1935) from 1948 to 1953 during a period of a severe inflationary spiral. As far as costs were concerned, an attempt was made to control them through measures such as the order of 13 February 1953 which established a reduction in the price of pharmaceutical products for sickness insurance, or the introduction of a renewable health care card in order to eradicate fraudulent claims. ${ }^{64}$ But the deficit of compulsory sickness insurance continued to grow, from 17.8 million in 1949 to 53.7 million in 1950. This deficit was covered by a special reserve created by the National Welfare Institute and with the surplus from the family allowances. ${ }^{65}$ Moreover, the high level of fraud by employers who did not pay what they ought to, or paid for a smaller number of workers than they actually employed, must be added to all the other factors. ${ }^{66}$ In this context, the debt that the collaborating bodies had with the National Welfare Institute also increased as they failed to transfer the amount required to cover the National Health Care Facilities Plan (Plan Nacional de Instalaciones Sanitarias) and the related Inspection Services due to financial problems. In 1950, the most important collaborating body in terms of volume of premiums, Mutua General de Seguros, owed the National Welfare Institute 6 million pesetas for the national plan and 1.3 million pesetas for inspections. ${ }^{67}$ This situation called into question not only the management of the insurance in private hands but also the the impossibility of financing this type of insurance through a contributory system maintained by very low wages.

\footnotetext{
${ }^{64}$ Gil, 'El Seguro Obligatorio'. The National Welfare Institute itself had commited a serious error as at the time the compulsory sickness insurance was introduced, the Institute's actuarial service calculated a monthly pharmaceutical cost per insured of 4.38 pesetas, when in reality it was set almost from the beginning at 13 pesetas a month. González Murillo, 'El franquismo social', 108.

${ }^{65}$ Jordana, Los seguros sociales, 161.

${ }^{66}$ González Murillo, 'La política social’, 71.

${ }^{67}$ The volumen of premiums collected by this entity was 203.3 million pesetas. Pons, 'El seguro obligatorio'.
} 
On the other hand, the number of Spaniards who benefited from the coverage against sickness grew slowly during this period. In its first stages the sickness insurance only applied to industrial workers and their families. This meant that almost 50 percent of Spain's active population, who still worked in agriculture in 1950, were left unprotected. Another important group of workers, those employed in domestic service, was also left outside the coverage of the insurance. ${ }^{68}$ Although the theoretical limit of possible beneficiaries was around 85 percent of the Spanish population (25.3 million in 1959), it had only been possible to reach a figure of around 37.5 percent that year (Table 2). ${ }^{69}$ The various attempts to introduce a special agricultural regime in rural areas were doomed to failure. Although there was an attempt to apply a special version of compulsory sickness insurance to casual agricultural workers from 1943 on, by 1956 this had still not been put into practise. This was due to a large extent to its rejection by employers. The largest collaborating body operating in the agricultural sector, MAPFRE, abandoned the special agreement in 1954 with a substantial deficit. ${ }^{70}$ Consequently, the majority of agricultural workers remained without protection, even despite the creation of national service for agricultural security (Servicio Nacional de Seguridad Agraria) in 1958 and a national mutual society for agricultural insurance (Mutualidad Nacional de Previsión Agraria) in 1959. ${ }^{71}$

Table 2. Population covered by the sickness insurance in Spain

\begin{tabular}{|l|l|l|l|l|l|}
\hline & Beneficiaries & Insured & Population & \% Beneficiaries & \% Insured \\
\hline 1944 & $6,828,946$ & $2,143,671$ & $26,594,000$ & 25.68 & 8.06 \\
\hline
\end{tabular}

\footnotetext{
${ }^{68}$ In 1950 the agricultural population comprised 47,6\% of Spain's active population. Data in Nicolau, 'Población, salud y actividad', 150.

${ }^{69}$ INP, Servicio de Prestaciones Sanitarias.

${ }^{70}$ Hernando, Así se hizo Mapfre, 233.

${ }^{71}$ González Murillo, 'El franquismo social', 97-98.
} 


\begin{tabular}{|l|l|l|l|l|l|}
\hline 1945 & $7,313,504$ & $2,521,866$ & $26,802,000$ & 27.29 & 9.41 \\
\hline 1946 & $7,698,543$ & $2,749,088$ & $27,012,000$ & 28.50 & 10.18 \\
\hline 1947 & $8,320,504$ & $3,034,106$ & $27,223,000$ & 30.56 & 11.15 \\
\hline 1948 & $8,546,451$ & $3,166,296$ & $27,437,000$ & 31.15 & 11.54 \\
\hline 1949 & $8,379,853$ & $3,131,501$ & $27,651,000$ & 30.31 & 11.33 \\
\hline 1950 & $8,180,636$ & $3,064,641$ & $27,868,000$ & 29.35 & 11.00 \\
\hline 1951 & $8,402,395$ & $3,145,194$ & $28,806,000$ & 29.17 & 10.92 \\
\hline 1952 & $8,766,544$ & $3,297,287$ & $28,332,000$ & 30.94 & 11.64 \\
\hline 1953 & $8,707,754$ & $3,719,362$ & $28,571,000$ & 30.48 & 13.02 \\
\hline 1954 & $8,999,579$ & $3,621,110$ & $28,812,000$ & 31.24 & 12.57 \\
\hline 1955 & $9,380,752$ & $3,784,376$ & $29,056,000$ & 32.29 & 13.02 \\
\hline 1956 & $9,805,882$ & $3,978,337$ & $29,301,000$ & 33.47 & 13.58 \\
\hline 1957 & $10,221,209$ & $4,141,382$ & $29,548,000$ & 34.59 & 14.02 \\
\hline
\end{tabular}

Población de Nicolau, 'Población, Salud'. Data of compulsory sickness insurance from the Anuarios Estadísticos de España, 1950, 1955 and 1960.

As well as the fact that only a small proportion of the population was covered, it should also be noted that there was a shortage of health care infrastructure. In the first National Health Care Facilities Plan drawn up on 19 February 1945, the creation of 86 large hospitals which would provide 24,000 beds was envisaged, along with 149 complete health centers and 110 reduced ones, and 73 maternity and infant institutions with 6,500 beds. $^{72}$ The plan was revised and modified by an order of 26 February 1947, with a reduction in the number of constructions planned, and which was ultimately included as 68 hospitals, 62 complete health centers and 144 small clinics with a limited number of specialities, with a

\footnotetext{
${ }^{72}$ INP, Hojas divulgadoras.
} 
total of 273 health care institutions and 16,114 beds. ${ }^{73}$ The plan was to be put into effect in two stages, each one of five years, and the budget calculated for the execution of the plan was 1,000 million pesetas. The initial propaganda had to be progressively revised with more realistic expectations. According to the heads of the National Welfare Institute, the building of 29 large hospitals and 30 health centers had started in 1950. Of all these, only the work of the hospitals of La Coruna, Guadalajara and Valencia, and the health centers of Ferrol, Alcoy, Bilbao and Pampliega had been totally completed by 31 December 1950 . Furthermore, by 1953 only 9 hospitals and 18 health centers of the plan were up and running, and these had not been built in the areas where the need for beds was most acute. ${ }^{74}$ In spite of the National Health Care Facilities Plan which had created hospitals and health centers, the number of beds per inhabitant showed clear deficiencies in a substantial part of Spanish territory. In 1957, the compulsory sickness insurance had 90 clinics and 12,962 beds at its disposal. However, half of the hospitals, 46 , were the property of collaborating bodies, and the majority of these were small centers with a total capacity of only 3,564 beds. $^{75}$ The best-equipped region was Barcelona, which in 1959 had a ratio of 803 inhabitants per bed, but this was thanks to the contribution of the collaborating bodies and not due to the contribution made through the plan. According to the government, the optimum ratio was 1 bed for every 2,000 inhabitants. ${ }^{76}$ But there was a very important regional imbalance in the availability of hospitals and health centers, as other important cities such as Madrid (with 14,901 inhabitants

\footnotetext{
${ }^{73}$ Jordana, Los seguros sociales, 128.

${ }^{74}$ INP, Diversos problemas actuales.

${ }^{75}$ INP, Servicio de Prestaciones Sanitarias.

${ }^{76}$ Barcelona had 28 large hospitals (residencias sanitarias) in 1957, but only one was public, the other 27 belonged to collaborating bodies. Of the 3,094 beds available, 2,352 were beds of the collaborating bodies. INP, Servicio de Prestaciones Sanitarias, no. 2.
} 
per bed) had a worse ratio, and the province of Guipúzcoa had a ratio of 6,600 inhabitants per bed.

The end of the special agreements in 1954 gave rise to a new regime of collaboration with regard to compulsory sickness insurance. With the Ministry of Labor's decree of 20 July 1954 new rules were issued regulating the management of collaborating bodies. The deposit these entities had to pay was increased, the premium fixed for workers' earned income was 9 percent and administration costs were reduced to 13 percent. However, some collaborating bodies renounced the option of renewing their agreements because the situation of crisis had put their own survival at risk.

The situation in 1957, however, was still a long way from meeting a statement which, in a publication of the National Welfare Institute, was attributed to Franco: 'Today the Spanish worker, thanks to the sickness insurance, enjoys better clinics, and the same appliances and such good doctors as any wealthy patient' ${ }^{77}$ This statement was far from being the case, but even if it had been true, it would have been at the expense of part of the wage of industrial workers, at the expense of their effort and of putting up with hardships in order to feed their families, at the expense of their exploitation and not that of the state's resources. The state's participation in the financing of this insurance was very limited, and through specific subsidies such as the extraordinary subsidy of $1957 .^{78}$ After a ministerial crisis on 25 February 1957, the need for change in the management and financing of the social insurances in general, and in compulsory sickness insurance in particular, gave rise to a debate about a National Social Security Scheme which finally led to end of the private management of this social insurance in $1963 .^{79}$

\footnotetext{
${ }^{77}$ Statement included in INP, 'Plan Nacional de Instalaciones Sanitarias'.

${ }^{78}$ González Murillo, 'El franquismo social', 98-99.

${ }^{79}$ For this new stage, see Martínez Quinteiro, 'El INP entre 1957-1978'.
} 


\section{Conclusions}

In 1954, the Minister of Labor, José A. Girón, declared that 'Spanish social security is among the cheapest in the world' ${ }^{80}$ Girón's words were correct if we analyze the situation from the point of view of the state's coffers. The Franco dictatorship did not commit itself to financing its social policy on a regular basis and passed on the expenses of the system to employers and workers. The workers got the worst of the deal as they had to endure a further reduction in what were already low wages due to the contributions towards social insurances and other social charges.

In the middle of the repression, the hunger and the poverty of the majority of the Spanish population, the Franco dictatorship tried to disguise the harsh reality with a propagandainspired social policy which, in theory, covered the most vulnerable sectors of the population. The social insurances were its main assets, the friendly face of the authoritarian regime, while in labor issues a repressive and rigid regime was established for workers. The Franco dictatorship inherited a disorganized system of social insurances with an irregular management. This legacy was not essentially modified, but the authorities tried to introduce the most complex insurance, which was given a central role in the regime's social policy: sickness insurance. During the postwar period, the obstacles which had impeded its application before the Civil War continued: a regressive tax system and limited support from doctors and workers. The new regime's interest in a populist social policy, and especially the support provided by Falangists in key ministries in the first years, meant that, in spite of the lack of financing, the new insurance prevailed, although it was a work insurance given that its financing was only feasible through the contributions of workers and employers.

\footnotetext{
${ }^{80}$ ABC newspaper, 15 June 1954, 39.
} 
Nevertheless, an analysis of its management, financing, health care infrastructure and its provisions in the first fifteen years make its scant results more than evident. Moreover, it is quite clear that the state does not deserve any credit even for these minimal results. Financing was through contributions, with a greater impact of the premiums on workers' real wages, which were in decline during the first fifteen years. The greater part of the management was transferred to private entities, which obtained important deficits at the time when the benefits were extended to include medical and legal specialities, inflation was rising and pharmaceutical expenses were rocketing. The benefits were insufficient and only covered industrial workers, excluding casual agricultural workers and fishermen, those working in domestic service and other groups of workers.

The great problem for the state to implement this insurance in the nineteen twenties had been the difficulties in financing the project. Due to a backwardness in the tax system, the state did not have sufficient resources to hire medical personnel or to create the clinics and hospitals necessary to provide medical care for the majority of the Spanish people. The Franco regime did not modify the problem, but rather limited itself to taking advantage of its repressive power to set up a system where employers and workers financed the insurance. Doctors and specialists, medicines and monetary benefits were all paid for through the deduction of premiums from wages and employers' contributions. Furthermore, the same source was expected to finance the plans to create large hospitals in the main cities and even to compulsorily finance the inspection of the entire system. The results were not as envisaged: deficit in the management of the scheme, a very slow increase in the number of beneficiaries and far fewer hospitals and health centers than originally planned for the first ten years that the insurance was in operation. Moreover, these hospitals were not built in the areas where there was the greatest need for beds, so after the insurance had been functioning for fifteen 
years the shortage in the most populated areas continued and there were great regional imbalances.

The increase of state financing, despite the fact that it proceeded from a regressive tax system, enabled sickness insurance to be consolidated and the creation of an infrastructure that in the long term would benefit almost the entire population. All the problems surrounding sickness insurance started to prompt the search for a new model, a search which finally led to a law of social security in 1963 in which, this time, a state contribution was contemplated.

\section{References}

Alberti López, Luis. 'La asistencia sanitaria en el conjunto de la previsión social española'. In VV.AA, De la beneficencia al bienestar social. Madrid: Siglo XXI, 1988.

Álvarez Roseta, Arturo. ‘Bienvenido, Mister Beveridge! El viaje de William Beveridge a España y la Previsión Social Franquista'. Internacional Journal of Iberian Studies 17 (2) (2004): 105-116.

Álvarez Rosete, Arturo. 'Elaborados con calma, ejecutados con prisa'. El avance de los seguros sociales y la evolución del Instituto Nacional de Previsión en España entre1836 y 1950’. In La previsión social en la historia, coord. Santiago Castillo and Rafael Rusaza, 255- 263. Madrid: Siglo XXI, 2009.

Aparicio, Miguel A. 'Sobre los comienzos del sindicalismo franquista, 1939-1945'. In España bajo el franquismo, ed. Josep Fontana, 78-99. Barcelona: Crítica, 1986.

Babiano Mora, José. Paternalismo industrial y disciplina fabril en España (1938-1958). Madrid: CES, 1998.

Barciela, Carlos (eds). Autarquía y mercado negro. El fracaso del primer franquismo, 19391959. Barcelona: Crítica, 2003. 
Barciela, Carlos, López, M. Inmaculada Melgarejo, Joaquín and José. A. Miranda. La España de Franco (1939-1975). Madrid: Síntesis, 2001.

Benjumea Pino, Pedro. 'Sanidad y desempleo.' In Historia de la acción social pública en España. Beneficencia y Previsión, VVAA, 449-471. Madrid: Ministerio de Trabajo y Seguridad Social, 1990.

Bernabeu-Mestre, Josep. 'La utopía reformadora de la Segunda República: la labor de Marcelino Pascua al frente de la Dirección General de Sanidad, 1931-1933'. Revista Española de Salud Pública 74 (2000): 1-13.

Bernabeu-Mestre, Josep. 'Madres y enfermeras. Demografía y salud en la política poblacionista del primer franquismo, 1939-1950’. Revista de Demografía Histórica XX, I, (2002): 123-143.

Bernal Martín, Salvador. El seguro obligatorio de enfermedad. Madrid: Librería General Victoriano Suárez, 1949.

Bertini, Fabio. 'Il fascismo dalle assicurazioni per i lavoratori allo stato sociale'. In Lo stato fascista, ed. Marco Palla. Milan: La Nuova Italia, 2001.

Bessel, Richard. Fascist Italy and Nazi Germany: comparisons and contrasts. Cambridge: Cambridge University Press, 1996.

Bikkal, Dénes. 'La Seguridad Social en España', Revista Iberoamericana de seguridad social 3 (1954): 411-453.

Blanco, Juan E. Planificación de la seguridad social española, Barcelona: Eds. Marte, 1964

Bowen, Wayne H. Spaniards and Nazi Germany: collaboration in the new order. Columbia and London: University of Missouri Press, 2000.

Castillo, Santiago (Dir.). Solidaridad, Seguridad, Bienestar. Cien años de protección social en España. Madrid: Ministerio de Trabajo e Inmigración, 2008. 
Catalan, Jordi. 'La reconstrucción franquista y la experiencia de la Europa Occidental, 19341959’. In Autarquía y mercado negro. El fracaso del primer franquismo, 1939-1959, ed. Carlos Barciela, 123-168. Barcelona: Crítica, 2003.

Catalan, Jordi. La economía española y la Segunda Guerra Mundial. Barcelona: Ariel, 1995.

Cenarro, Ángela. La sonrisa de Falange. Auxilio Social en la guerra civil y en la posguerra. Barcelona: Crítica, 2006.

Comín Comín, Francisco. Hacienda y economía en la España contemporánea (1800-1936), 2 vols. Madrid: Instituto de Estudios Fiscales, 1988.

Criado del Rey, Sebastián. Problemas Sanitarios del Seguro de Enfermedad. Madrid: INP, 1947.

Cuesta Bustillo, Josefina. 'Hacia el seguro de maternidad: la situación de la mujer obrera en los años veinte'. In Ordenamiento jurídico y realidad social de las mujeres. Siglo XVI a XX. Actas de las IV Jornadas de Investigación interdisciplinaria, 321-336. Madrid: Ediciones de la UAM.

García Padilla, Margarita. 'Historia de la acción social: seguridad social y asistencia (19391975)’. In Historia de la acción social pública en España. Beneficencia y Previsión, ed. José Álvarez Junco, 397-448. Madrid: Ministerio de Trabajo y Seguridad Social, 1990.

Gil Carretero, Santos. 'El Seguro Obligatorio de Enfermedad en 1952. Estudio Estadístico, con algunas consideraciones de carácter económico y financiero', Revista de Política Social 24 (1954): pp. 27-82.

González Murillo, Pedro. 'El franquismo social: propaganda y seguros a través del Instituto Nacional de Previsión (1939-1962)’. In Solidaridad, Seguridad, Bienestar. Cien años de protección social en España, ed. Santiago Castillo, 89-124. Madrid: Ministerio de Trabajo y Emigración, 2009. 
González Murillo, Pedro. 'La política social del franquismo: el seguro obligatorio de enfermedad'. Aportes 57 (2005): 62-76.

González, Manuel J. La economía política del franquismo (1940-1970). Dirigismo, mercado y planificación. Madrid: Tecnos, 1979.

Hermida Carlos. 'El retiro obrero obligatorio en España: génesis y desarrollo (1917-1931)'. Estudios de Historia Social 14 (1980): 7-60.

Hernando de Larramendi, Ignacio. Así se hizo Mapfre. Mi tiempo. Madrid: Actas Editorial, 2001.

Instituto Nacional de Previsión, INP. Plan Nacional de Instalaciones Sanitarias. Madrid: Ministerio de Trabajo, INP, Dirección de Asistencia Sanitaria e Instalaciones del Seguro de Enfermedad, 1953.

Instituto Nacional de Previsión, INP. Diversos problemas actuales del Seguro de Enfermedad y de su Plan Nacional de Instalaciones. Madrid: Ministerio de Trabajo, INP, 1953.

Instituto Nacional de Previsión, INP. Compendio del Seguro de Enfermedad. Madrid, 1949.

Instituto Nacional de Previsión, INP. Dirección de Asistencia Sanitaria e Instalaciones del Seguro de Enfermedad. Diciembre de 1953. Madrid: Ministerio de Trabajo, 1953.

Instituto Nacional de Previsión, INP. El seguro de Enfermedad y sus problemas: estudio para un plan general de instalaciones de asistencia médica. Madrid: Ministerio de Trabajo, 1944.

Instituto Nacional de Previsión, INP. Hojas divulgadoras del Seguro de Enfermedad, hoja No. 3. Madrid: Ministerio de Trabajo, 1946.

Instituto Nacional de Previsión, INP. Servicio de Prestaciones Sanitarias. Informe sobre la explotación de las instalaciones sanitarias del seguro de enfermedad. Madrid: Ministerio de Trabajo, 1959. 
Instituto Nacional de Previsión, INP. Servicio Exterior y Cultural. El plan de Instalaciones Sanitarias, Hoja Divulgadora nº 56. Madrid: Ministerio de Trabajo, 1947.

Jordana de Pozas, Luis. Los seguros sociales en España de 1936 a 1950. Madrid: Instituto Nacional de Previsión, 1953.

Marset Campos, Pedro. 'Estructura político-administrativas y salud pública en España'. Revista de Sanidad e Higiene Pública 68 (1994): 57-64.

Martínez Quinteiro, $M^{a}$ Esther. 'El INP entre 1957-1978: de los seguros sociales a la seguridad social franquista'. In Solidaridad, Seguridad, Bienestar. Cien años de protección social en España, ed. Santiago Castillo, 265-296. Madrid: Ministerio de Trabajo y emigración, 2009.

Molero Mesa, Jorge. 'Enfermedad y previsión social en España durante el primer franquismo (1936-1951). El frustado seguro obligatorio contra la tuberculosis'. Acta Hispanica and Medicinae Scientiarumque Historiam Illustrandam 14 (1994): 199-225.

Molinero, Carme. 'Mujer, franquismo, fascismo. La clausura forzada en un mundo pequeño'. Estudios de Historia Social, 30 (1998): 97-117.

Molinero, Carme. La captación de las masas. Política social y propaganda en el régimen franquista. Madrid: Cátedra, 2005.

Montero, Feliciano. Orígenes y antecedentes de la previsión social. Los seguros sociales en la España del siglo XX. Madrid: Ministerio de Trabajo y Seguridad Social, 1988.

Nicolau, Roser. 'Población salud y actividad'. In Estadísticas Históricas de España. Siglos XIX y XX, coord. Albert Carreras and Xavier Tafunell, 79-154. Madrid: Fundación BBVA, 2005.

Owen Smith, Eric. The German economy. London: Routledge, 1994.

Palacio Morena, Juan I. La construcción del Estado Social. Madrid: Consejo Económico y Social, 2004. 
Pereda Mateos, Antonio and Aurelio Desdentado Bonete. 'La política de salarios y los salarios de cotización y prestaciones a efectos de seguridad social'. Revista de Trabajo 31 (1970): 27-46.

Pons Pons, Jerònia and Margarita Vilar Rodríguez . 'Friendly societies, commercial insurance and the state in sickness risk coverage: the case of Spain (1880-1944)'. International Review of Social History 56, 1 (2011): 71-102.

Pons Pons, Jerònia. 'El seguro obligatorio de enfermedad y la gestión de las entidades colaboradoras (1942-1963)'. Revista de la Historia de la Economía y de la Empresa 4 (2010): 227-250.

Porras Gallo, Isabel. 'El seguro de enfermedad en la II República española: del decreto de 25 de diciembre de 1933 al Ier congreso Nacional de Sanidad'. In Estado, Protesta y Movimientos Sociales, Actas del III Congreso de Historia Social de España, VitoriaGasteiz, julio de 1997, ed. José M. Ortiz de Ortuño Legarda and Santiago Castillo, 171-176. Victoria-Gasteiz: Pub. Universidad del País Vasco, 1998.

Prados de la Escosura, Leandro. El progreso económico de España (1850-2000). Madrid: Fundación BBVA, 2003.

Preston, Paul. Franco. Caudillo de España. Barcelona: Grijalbo, 1994.

Redecillas López de Sabando, Antonio. El mutualismo laboral como medio de protección Social. Un estudio económico financiero. Madrid: Consejo Económico y Social (CES), 2001.

Richards, Michael. Un tiempo de silencio. La guerra civil y la cultura de la represión en la España de Franco, 1936-1945. Barcelona: Crítica, 1999.

Rodríguez Ocaña, Esteban. 'La asistencia médica colectiva en España hasta 1936'. In Historia de la Acción pública en España. Beneficencia y Previsión, ed. Juan J. Álvarez Junco, 321-361. Madrid: Ministerio de Trabajo y Seguridad Social, 1990. 
Rodríguez Ocaña, Esteban. 'Los servicios de salud pública en la España Contemporánea'. Trabajo Social y Salud 43 (2002): 91-118.

Rodríguez Ocaña, Esteban. 'The politics of public health in the state-managed scheme of healthcare in Spain (1940-1990)'. In Images of Disease. Science, Public Policy and Health in Post-war Europe, Eds. I. Löwy, \& J. Krige, 187-210. Luxembourg: European Communities, 2001.

Rull Sabater, Alberto. 'Consecuencias fiscales de una mayor participación del estado en la financiación de la seguridad social'. Revista de Trabajo, 30 (1970): 27-85.

Sánchez Recio, Glicerio and Julio Tascón Fernández. Los empresarios de Franco. Política y economía en España, 1936-1957. Barcelona: Critica, 2003.

Sarasúa, Carmen and Lina Gálvez (eds.). ¿Privilegios o eficiencia? Mujeres y hombres en los mercados de trabajo. San Vicente de Raspeig: Publicaciones de la Universidad de Alicante, 2003.

Serrano Guirado, Enrique. El seguro de enfermedad y sus problemas. Madrid: Instituto de Estudios Políticos, 1950.

Serrano Martínez, Antonio. and José Luis Malo de Molina. Salarios y Mercado de Trabajo en España. Madrid: H. Blume, 1979.

Tusell, Javier. La dictadura de Franco. Barcelona: Alianza Ed., 1996.

Vilar Rodríguez, Margarita. 'La distribución funcional de la renta en España entre 1914 y 1959: Una propuesta de análisis'. Investigaciones de Historia Económica 6 (2006): 105-136.

Vilar Rodríguez, Margarita. 'La ruptura postbélica a través del comportamiento de los salarios industriales: nueva evidencia cuantitativa (1908-1963)'. Revista de Historia Industrial 25 (2004): 81-126. 
Vilar Rodríguez, Margarita. Los salarios del miedo. Mercado de trabajo y crecimiento económico en España durante el franquismo. Santiago de Compostela: Fundación 10 Marzo, 2009.

Zamagni, Vera. The economic history of Italy, 1860-1990. Oxford: Oxford UP, 1993. 